\title{
The J. M. Snow Site (41CE8) in the Neches River Basin, Cherokee County, Texas
}

Timothy K. Perttula

Heritage Research Center, Stephen F. Austin State University

Follow this and additional works at: https://scholarworks.sfasu.edu/ita

Part of the American Material Culture Commons, Archaeological Anthropology Commons, Environmental Studies Commons, Other American Studies Commons, Other Arts and Humanities Commons, Other History of Art, Architecture, and Archaeology Commons, and the United States History Commons

Tell us how this article helped you.

This Article is brought to you for free and open access by the Center for Regional Heritage Research at SFA ScholarWorks. It has been accepted for inclusion in Index of Texas Archaeology: Open Access Gray Literature from the Lone Star State by an authorized editor of SFA ScholarWorks. For more information, please contact cdsscholarworks@sfasu.edu. 


\section{The J. M. Snow Site (41CE8) in the Neches River Basin, Cherokee County, Texas Creative Commons License (c) $($ ) $(9)$}

This work is licensed under a Creative Commons Attribution-NonCommercial 4.0 International License 


\title{
The J. M. Snow Site (41CE8) in the Neches River Basin, Cherokee County, Texas
}

\author{
Timothy K. Perttula
}

\section{INTRODUCTION AND SITE SETTING}

The J. M. Snow site (41CE8) is an ancestral Caddo habitation site and probable small cemetery in the Pineywoods of East Texas (Figure 1). According to Jackson (1933), the site had two habitation areas along the bank of an old channel of the Neches River, each some $300 \mathrm{~m}$ from an area where the landowner found 8-10 ceramic vessels from one or more burials that had eroded into a ravine. A Bullard Brushed jar was purchased from the landowner

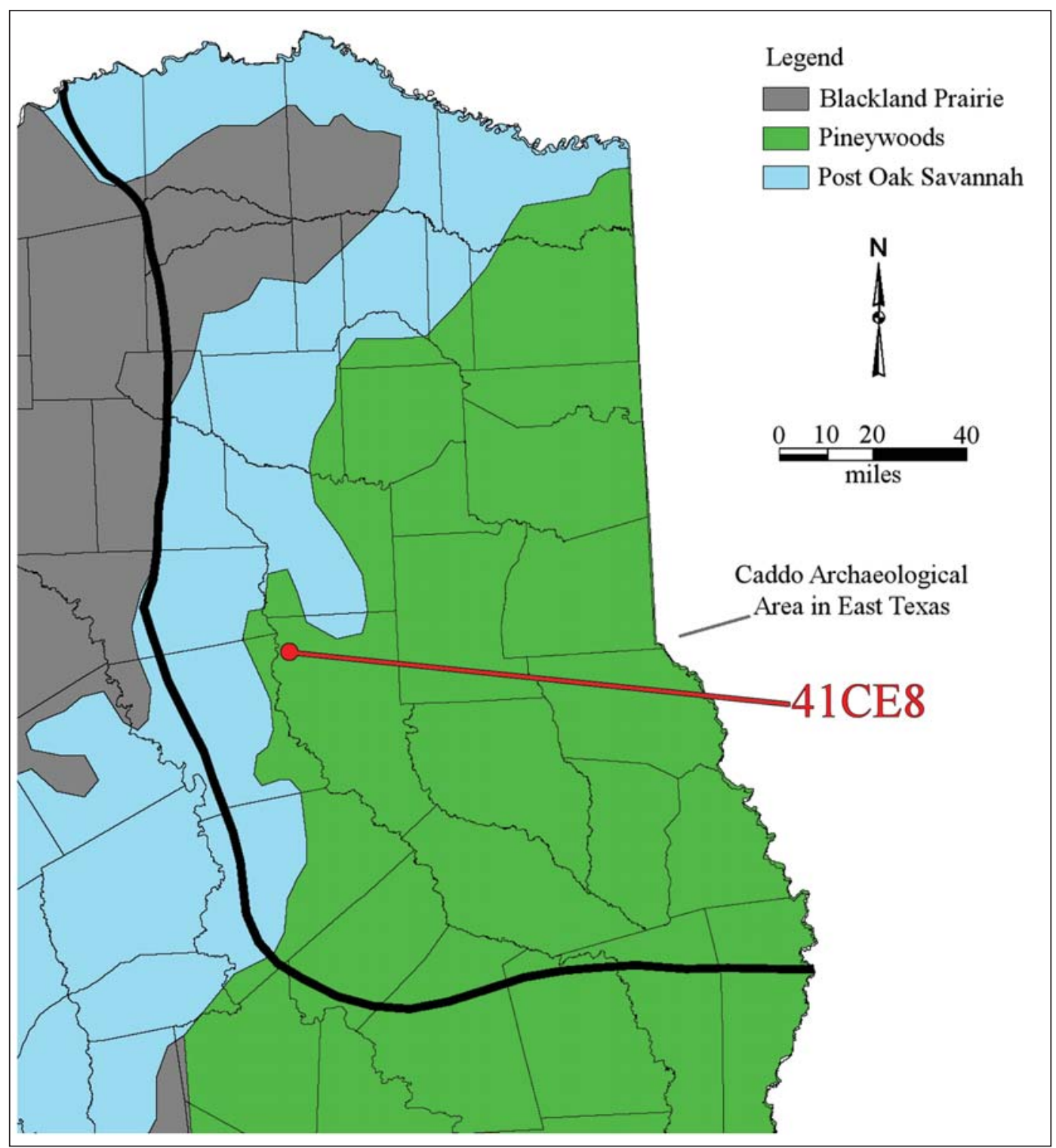

Figure 1. The location of the J. M. Snow site (41CE8) in East Texas. 
One of the habitation areas had a well-preserved midden deposit about 4.6-7.6 $\mathrm{m}$ in diameter and ca. 46-76 cm in thickness. University of Texas (UT) excavations in September 1933 concentrated on this midden deposit. The work recovered burned clay, mussel shells, ash, bone awls $(\mathrm{n}=2)$, perforated mussel shells, bone beads ( $\mathrm{n}=2)$, lithic scrapers, deer antler tools, and deer, dog, raccoon, turtle, turkey, fish, rabbit, and squirrel bone refuse, as well as ceramic pipe sherds and many ceramic vessel sherds.

\section{Ceramic Vessel Sherd Assemblage}

There are 519 ceramic sherds in the collections at the Texas Archeological Research Laboratory from the J. M. Snow site (Table 1). About 73 percent of the sherds are from utility ware jars of the Bullard Brushed type, mainly decorated with brushing marks on the rim and body (Table 1). Only about 18 percent of the sherds are plain, and the remaining 9 percent of the sherds are from engraved fine ware vessels.

Table 1. Ceramic vessel sherd assemblage from the J. M. Snow site (41CE8).

\begin{tabular}{ll}
\hline Ware/ & $\mathrm{N}$ \\
Decorative method & \\
\hline Plain ware & 95 \\
Utility ware & 1 \\
Appliqued & 340 \\
Brushed & 1 \\
Brushed-Incised & 13 \\
Brushed-Punctated & 11 \\
Incised & 4 \\
Neck Banded & 3 \\
$\quad$ Pinched & 4 \\
$\quad$ Punctated & 47 \\
$\quad$ Fingraved & 519 \\
\hline Totals & \\
\hline
\end{tabular}

Of those sherds analyzed by temper inclusions, approximately 95 percent $(n=413)$ are from vessels tempered with grog; the remainder of these sherds $(n=23)$ are from bone-tempered vessels. The high proportion of grog-tempered vessels is consistent with other known upper Neches River basin Late Caddo ceramic assemblages (Perttula 2011).

In addition to the many Bullard Brushed sherds (and the one vessel purchased by UT from the landowner), there are Maydelle Incised, Killough Pinched, and La Rue Neck Banded utility ware sherds in the assemblage from the site. There is also one grog-tempered Spradley Brushed-Incised sherd in the assemblage. This utility ware is found on post-A.D. 1650 Historic Caddo Allen phase sites in the Neches-Angelina river basins in East Texas. It consists of parallel brushing elements with overlapping straight incised lines that are opposed or perpendicular to the brushing (Marceaux 2011:140 and Figure 5.2).

The fine wares are represented by sherds from a Hume Engraved bottle, Poynor Engraved carinated bowl, and Poynor/Patton Engraved sherds. These represent the latest stylistic expression of the Poynor Engraved type, likely Poynor Engraved, var. Freeman (see Perttula 2011), and probably date to the late $16^{\text {th }}$ and early $17^{\text {th }}$ centuries (ca. A.D. $1560-1650$ ). 


\section{Ceramic Pipe Sherds}

The pipe sherds $(n=4)$ from the J. M. Snow site are from short stem elbow pipes with flaring bowls that have either punctated, engraved, or incised decorations on the stem. These are Var. B and Var. C. Late Caddo elbow pipes in the upper Neches River basin (Perttula 2011:Figure 6-23).

\section{SUMMARY AND CONCLUSIONS}

The J. M. Snow site is a late Frankston phase (ca. A.D. 1560-1650) habitation site in the upper Neches River basin. UT excavations in 1933 in a well-preserved midden deposit along an old channel of the Neches River recovered a ceramic vessel sherd assemblage dominated by grog-tempered brushed vessels (Bullard Brushed), other utility ware and fine ware vessel sherds from types such as Maydelle Incised, Killough Pinched, La Rue Neck Banded, Hume Engraved, and Poynor Engraved, as well as decorated short stem elbow pipes consistent with the likely age of the ancestral Caddo component.

\section{ACKNOWLEDGMENTS}

I would like to thank Jonathan Jarvis of the Texas Archeological Research Laboratory at The University of Texas at Austin for facilitating access to the collections and records from the J. M. Snow site. Lance Trask prepared Figure 1.

\section{REFERENCES CITED}

Jackson, A. T.

1933 J. M. Snow Farm, 4 Miles N.W. of Reese, Cherokee County, Texas Excavated September 4 to September 9, 1933. MS on file, Texas Archeological Research Laboratory, The University of Texas at Austin.

Marceaux, P. S.

2011 The Archaeology and Ethnohistory of the Hasinai Caddo: Material Culture and the Course of European Contact. Ph.D. dissertation, Department of Anthropology, The University of Texas at Austin.

Perttula, T. K.

2011 The Ceramic Artifacts from the Lang Pasture Site (41AN38) and the Place of the Site within an Upper Neches River Basin Caddo Ceramic Tradition. In Archeological Investigations at the Lang Pasture Site (41AN38) in the Upper Neches River Basin of East Texas, assembled and edited by T. K. Perttula, D. B. Kelley, and R. A. Ricklis, pp. 145-320. Archeological Studies Program Report No. 129, Texas Department of Transportation, Environmental Affairs Division, Austin. 